\title{
The Place of Serials in
} Referencing Practices:

Comparing Natural Sciences and

Engineering with Social Sciences and Humanities

\section{Vincent Larivière Éric Archambault Yves Gingras Étienne Vignola-Gagné \\ 2005-05}




\section{Adresse postale}

\section{CIRST}

Université du Québec à Montréal

C.P. 8888 , Succursale Centre-ville

Montréal (Québec)

Canada, H3C 3P8

\section{Adresse civique}

\section{CIRST}

Université du Québec à Montréal

Pavillon Thérèse-Casgrain, 3e étage

455, boul. René-Lévesque Est, Bureau W-3042

Montréal (Québec) Canada

H2L 4Y2

\section{Pour nous joindre}

Téléphone : (514) 987-4018

Télécopieur : (514) 987-7726

Courrier électronique : cirst@uqam.ca

Site Internet : www.cirst.uqam.ca 


\section{TABLE OF CONTENTS}

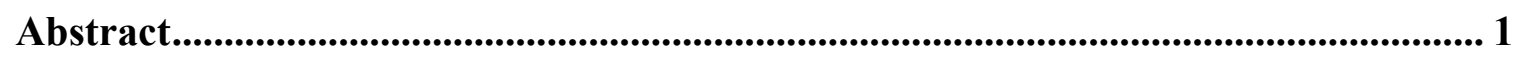

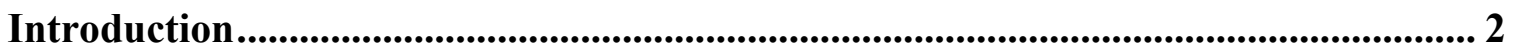

Non-journal publications in the social sciences and humanities.................................. 3

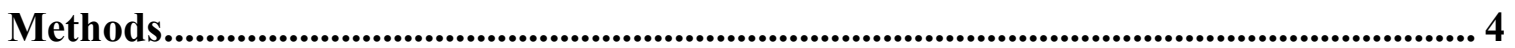

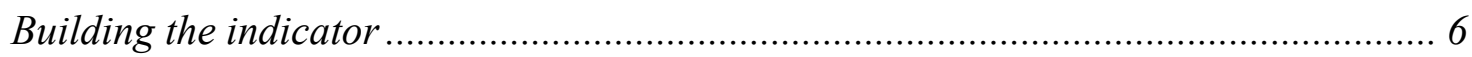

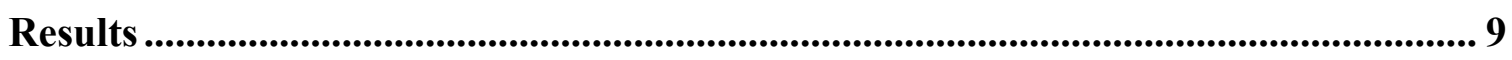

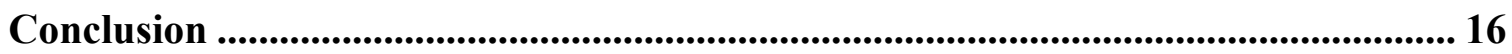

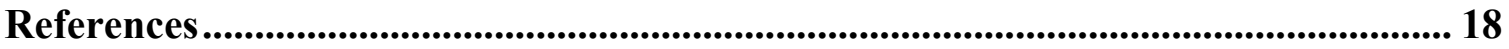





\section{Acknowledgments ${ }^{1}$}

This research was funded in part by the Social Sciences and Humanities Research Council of Canada (SSHRC). The authors would like to thank Sylvie Paquette and Hélène Régnier of SSHRC for their help in building aggregate classifications of disciplinary fields in the social sciences and humanities. We are also indebted to François Vallières of the Observatoire des sciences et des technologies (OST) for constructing the bibliometric database and to Jean Lebel for commenting on a previous version of this paper. Finally, we wish to acknowledge the comments and suggestions made by the two anonymous referees.

\footnotetext{
${ }^{1}$ This paper is a preprint of an article accepted for publication in the Journal of the American Society for Information Science and Technology (JASIST) Ccopyright (2005) (Wiley Periodicals, Inc., A Wiley Company)
} 



\begin{abstract}
Journal articles constitute the core documents for the diffusion of knowledge in the natural sciences. It has been argued that the same is not true for the social sciences and humanities where knowledge is more often disseminated in monographs that are not indexed in the journal-based databases used for bibliometric analysis. Previous studies have made only partial assessments of the role played by both serials and other types of literature. The importance of journal literature in the various scientific fields has therefore not been systematically characterized. Our paper addresses this issue by providing a systematic measurement of the role played by journal literature in the building of knowledge in both the natural sciences and engineering and the social sciences and humanities. Using citation data from the CD-ROM versions of the SCI, SSCI and AHCI databases from 1981 to 2000, this paper quantifies the share of citations to both serials and other types of literature. Variations in time and between fields are also analyzed. The paper shows that journal literature is increasingly important in the natural and social sciences, but that its role in the humanities is stagnant and has even tended to diminish slightly in the 1990s. Since journal literature accounts for less than $50 \%$ of the citations in several disciplines of the social sciences and humanities, special care should be used when using bibliometric indicators that rely only on journal literature.
\end{abstract}




\section{Introduction}

Bibliometrics and other quantitative methods are being used increasingly in research evaluation because of the growing concern about accountability of public spending in science (King 1987; Treasury Board of Canada Secretariat 2001). While the validity and appropriateness of bibliometric methods are largely accepted in the natural sciences, the situation is more complex in the case of the social sciences and humanities. Bibliometricians who evaluate research output in the natural sciences can rely on a well-defined set of core journals that contains the most cited research and is covered comprehensively by both disciplinary and interdisciplinary databases. The same cannot be said about the social sciences and humanities.

Hicks (1999 and 2004) recently summarized the difficulties surrounding the use of bibliometrics for the social sciences and humanities (SSH). Research in these domains is much more interdisciplinary than in the natural sciences and engineering (NSE). This situation often leaves researchers no choice but to use multidisciplinary databases, especially if citation analysis is to be performed. The combined use of Thomson ISI's Social Sciences Citation Index (SSCI) and Arts and Humanities Citation Index (AHCI) can hardly be avoided given their extensive coverage. But their use is not without problems. Within the context of an analysis restricted to journal articles, the SSCI and AHCI fail to cover a good part of the literature published outside the United States and the United Kingdom, whether the language used is English or not. In fact, many authors consider these databases to be biased in favor of those two countries (Andersen 2000; Glänzel 1996; Nederhof and Noyons 1992; Schoepflin 1992; Webster 1998). The adequacy of the SSCI and $\mathrm{AHCI}$ to evaluate SSH research is even more problematic when one considers the importance of books and other types of documents in the process of scholarly communication in these fields. For instance, Hicks (2004) convincingly argues that books not only form a sizeable part of publications in some disciplines of the social sciences and humanities but are also often cited, and

\footnotetext{
Page 2 | CIRST - Note de recherche 2005-05
} 
The Place of Serials in Referencing Practices: Comparing Natural Sciences and Engineering with Social Sciences and Humanities

this impact cannot be extrapolated from that of journal articles. Thus, the validity of evaluations using bibliometric methods and Thomson ISI's databases can only be properly assessed if the share of the various types of documents being used in scholarly communication is known. This paper measures the importance of these different types of publications by looking at how often scientific journals are cited and, by extension, at how often other types of document are cited.

\section{Non-journal publications in the social sciences and humanities}

Numerous studies have provided data on the relative proportion of journal and non-journal forms of publishing. For instance, Nederhof et al. (1989) measured the percentage of journal articles, report proceedings and books (including edited books and book chapters) published by a sample of Dutch universities' departments ${ }^{2}$. He found that, for most of the departments, the results oscillated between $35 \%$ and $50 \%$ for papers and between $35 \%$ and $40 \%$ for books. Likewise, in their analysis of social science co-citation clusters, Small and Crane (1979) found that 39\% of cited items in sociology were books, $24.5 \%$ in economics, compared to only $0.9 \%$ in high-energy physics. Based on these results, Hicks (1999) estimated that between $40 \%$ and $60 \%$ of the literature in the social sciences is composed of books.

In a survey of 618 social scientists, Andersen (2000) found that only a quarter of their publications were journal articles. Studying six economics research groups from 1980 to 1988, Nederhof and van Raan (1993) found that $37 \%$ of the groups' combined production was composed of journal articles. Within the framework of the Research Assessment Exercise (RAE) in the United Kingdom, Norris and Oppenheim (2003) evaluated the performance of 682 archaeologists. The authors found that $54 \%$ of the archaeologists' publications were monographs and $40 \%$ articles. In addition, Leydesdorff (2003) showed that whereas $79 \%$ of citations in

\footnotetext{
${ }^{2}$ These departments specialized in anthropology, experimental psychology, social history, Dutch literature, Dutch language, general literature, general linguistics and public administration.
} 
Vincent Larivière, Éric Archambault, Yves Gingras et Étienne Vignola-Gagné

articles covered by the Science Citation Index (SCI) were to other articles included in the database, this percentage was only $45 \%$ for the Social Sciences Citation Index (SSCI). Glänzel and Schoepflin (1999), using a method similar to the one used in the present paper, found that the percentage of references to serials in the SCI and SSCI varied between $35 \%$ in history, philosophy of science and social sciences and 94\% in immunology.

In summary, all these studies claim that non-journal literature is more important in scholarly communication in the social sciences and humanities than it is in the natural sciences and engineering. However, none provides comprehensive data as to the importance of this difference for all disciplines and its evolution over a long period of time. The results are mostly limited to either national or institutional levels or represent only a static view of publication practices. The present paper addresses these issues by analyzing the number of references made to journal and non-journal literature by journals covered in the SCI, SSCI and AHCI databases from 1981 to 2000. The results provide important data for the evaluation of the role played by non-serial publications in various disciplines and their temporal evolution. This paper thus contributes to assessing how journal-centric databases can be used to evaluate scientific outputs in SSH disciplines in which publications other than articles still play an important role.

\section{Methods}

The data used in this paper are drawn from the CD-ROM version of the SCI, SSCI and AHCI. For the natural sciences, journals were assigned fields and subfields using the classification system developed by CHI Research ${ }^{3}$. In order to avoid double-counting, CHI's system never places a journal in more than one field. The classification is divided into nine major fields, which are again broken down into more than one hundred specialties or subfields. However, CHI does

\footnotetext{
${ }^{3} \mathrm{CHI}$ Research is a research firm specializing in quantitative science and technology research. For further information: http://www.chiresearch.com
}

Page 4 | CIRST - Note de recherche 2005-05 
not have a similar classification for the social sciences and the humanities. It was thus necessary to create a similar classification system for the SSH. ISI's classification of journals for the SSCI and AHCI was used as a starting point for creating eight SSH fields. Considering the fact that Thomson ISI assigns journals to more than one subfield, it was necessary to select the most relevant subfield for each journal to avoid double-counting references and papers when the data were aggregated by subfield.

This paper uses the Thomson ISI databases as a way of measuring referencing practices in different disciplines. It does not address other important issues such as the coverage of these databases by subfields. It concentrates on computing the proportion of serials and other types of document cited over a period of 20 years. Cited literature can be considered relevant, cumulative knowledge (both positive and negative) that results from a process of "scientific selection." Hence, this paper measures the relative importance of journal literature in knowledge-building in various NSE and SSH disciplines. In addition, one can hypothesize that referencing practices reflect publication practices and, therefore, that the proportion of serials in the references made by journal articles should by and large reflect the relative production of articles by scholars. Accordingly, quantitatively evaluating the presence of non-serials provides a measure of both the importance of other types of document such as books, which, as we have seen, play an important role in $\mathrm{SSH}$, and the evolution in time of the trend to produce journal articles rather than books. 
Vincent Larivière, Éric Archambault, Yves Gingras et Étienne Vignola-Gagné

\section{Building the indicator}

The indicator needed to address our research question is similar to that used by Glänzel and Schoepflin (1999). In their study of how journal literature aged in the natural and social sciences, they describe a method to isolate citations made to serials $(\mathrm{S})$ as opposed to citations made to non-serial literature $(\mathrm{N})$. In order to be included in the S category, a reference needs to fulfill a list of criteria, the main one being the presence of volume and page numbers. References without a first page number needed to have a valid journal name and the string "in press" to be considered an S. Manual and computerized procedures were used to extract references from serials that had no volume numbers but had valid first pages. All other references were categorized as non-serial literature $(\mathrm{N})$.

Applying this method to a very large amount of data covering 20 years would have been impractical, especially when it came to manually classifying references. The main issue in building the indicator was to isolate references to journal articles from references to other types of scientific publication. This entailed using a purpose-built algorithm to parse the string of characters of the reference in order to separate the different types of information they contained. Using that algorithm, fields containing specific information such as the author's name, title of the work cited, volume number, page number and year of publication were created. Cases where the abovementioned variables were missing were labeled as null in the appropriate database field.

Observation of the data suggested that, for most fields, the presence of a volume number could be a sufficient criterion to distinguish journals from other types of literature. To validate our hypothesis, a random sample of 200 references (100 with a volume number and 100 without a volume number) were tested for each subfield. While some references were easy to authenticate as serials (J-MARKETING-RES, AM-SOCIOL-REV, etc.) or

\footnotetext{
Page 6 | CIRST - Note de recherche 2005-05
} 
as non-serials (THESIS-U-MINNESOTA, SCHELLENBERG-MEMOIRS, etc.), some other cases needed research on the web since their titles did not contained any discriminating evidence.

Table 1 shows that both error rates vary considerably across fields. Indeed, for the social sciences fields in which papers are an important medium for the diffusion of scholarly communication (psychology, law, economics and management, education and other social sciences), the error rate for references without a volume number were higher than for references with a volume number. This is hardly surprising, since the probability that a serial is cited - as opposed to a non-serial - is greater in these fields. Also, we noticed that a large part of these errors are caused by non-academic journals such as Fortune, The Wall Street Journal, or other newspapers that seldom have a volume number. Consequently, the share of serials could be slightly higher in these fields than the value obtained by our indicator.

On the opposite side, error rates for fields in the humanities (history, other humanities and literature) were higher for references with a volume number than for those without a volume number. Again, since in these fields non-serial literature is much more important, this comes as no surprise. A large part these errors are caused by monograph series that have volume numbers, or by encyclopaedias and dictionaries that have several volumes. On the whole, these error rates indicate that, for these fields, the share of serials in cited literature could be even lower than the value obtained by our method. 
Vincent Larivière, Éric Archambault, Yves Gingras et Étienne Vignola-Gagné

Table 1 Error rates for references with and without volume numbers, by field

\begin{tabular}{|c|c|c|}
\hline Field & $\begin{array}{r}\text { Error rate } \\
\text { Volumes } \\
\end{array}$ & $\begin{array}{r}\text { Error Rate } \\
\text { No Volume }\end{array}$ \\
\hline Economics and Management & $0 \%$ & $11 \%$ \\
\hline Education & $2 \%$ & $7 \%$ \\
\hline History & $11 \%$ & $0 \%$ \\
\hline Law & $4 \%$ & $18 \%$ \\
\hline Literature & $15 \%$ & $1 \%$ \\
\hline Other Humanities & $18 \%$ & $1 \%$ \\
\hline Other Social Sciences & $2 \%$ & $7 \%$ \\
\hline Psychology (SSH) & $1 \%$ & $4 \%$ \\
\hline Average SSCI/ AHCI & $7 \%$ & $6 \%$ \\
\hline Biology & $2 \%$ & $3 \%$ \\
\hline Biomedical Research & $1 \%$ & $13 \%$ \\
\hline Chemistry* & $1 \%(1 \%)$ & $33 \%(9 \%)$ \\
\hline Clinical Medicine & $0 \%$ & $12 \%$ \\
\hline Earth and Space Science & $8 \%$ & $6 \%$ \\
\hline Engineering & $2 \%$ & $0 \%$ \\
\hline Mathematics & $4 \%$ & $5 \%$ \\
\hline Physics & $2 \%$ & $4 \%$ \\
\hline Psychology (NSE) & $2 \%$ & $5 \%$ \\
\hline Average SCI & $3 \%(3 \%)$ & $9 \%(6 \%)$ \\
\hline
\end{tabular}

In the natural sciences, our method proved to be somewhat problematic in the field of chemistry where the criteria of having a volume number proved to be insufficient to distinguish periodicals from non-periodicals. However, by using the search strings *-J-*, $\mathrm{J}_{-} *$, *-J (for journal) or *lett* (for letter) in the journal field, it was possible to isolate a large part of these errors. The recalculated error rate that takes into account this more complex search is presented in parentheses in Table 1. 
For other natural sciences fields, other types of error included book series that have volume numbers, especially in mathematics and engineering. In physics, preprints and eprint stored in archives such as arXiv account for an important share of non serial literature. In all cases, there is a high tendency to underestimate the share of serials in the natural sciences fields. For all fields, references to material that is "in press" created an error that tended to underestimate the number of citations to journal articles.

Taking into account that this study is performed at the macro level of analysis, this small potential measurement error does not adversely affect the global results in a significant manner. Since we aren't analyzing the fine structure of the spectrum, these error rates do not affect global results.

\section{Results}

Figure 1 shows that, by and large, the proportion of citations to journals in SSH journal literature is half of that observed in NSE. In particular, in 1981, the share of total citations to journal papers was slightly over $82 \%$ in NSE as opposed to $40 \%$ in SSH. Because the share of citations to periodicals grew faster in SSH than it did in SSE, this gap narrowed somewhat in 2000 with $49 \%$ of citations in SSH being made to journal papers, compared to $87 \%$ in NSE. Though small, this growth indicates a general trend toward a greater use of journals as a diffusion mechanism in SSH as a whole, the slope of which varies, however, according to discipline, as we will now see. 
Vincent Larivière, Éric Archambault, Yves Gingras et Étienne Vignola-Gagné

Figure 1 Share of references made to journal articles for NSE and SSH, 1981-2000

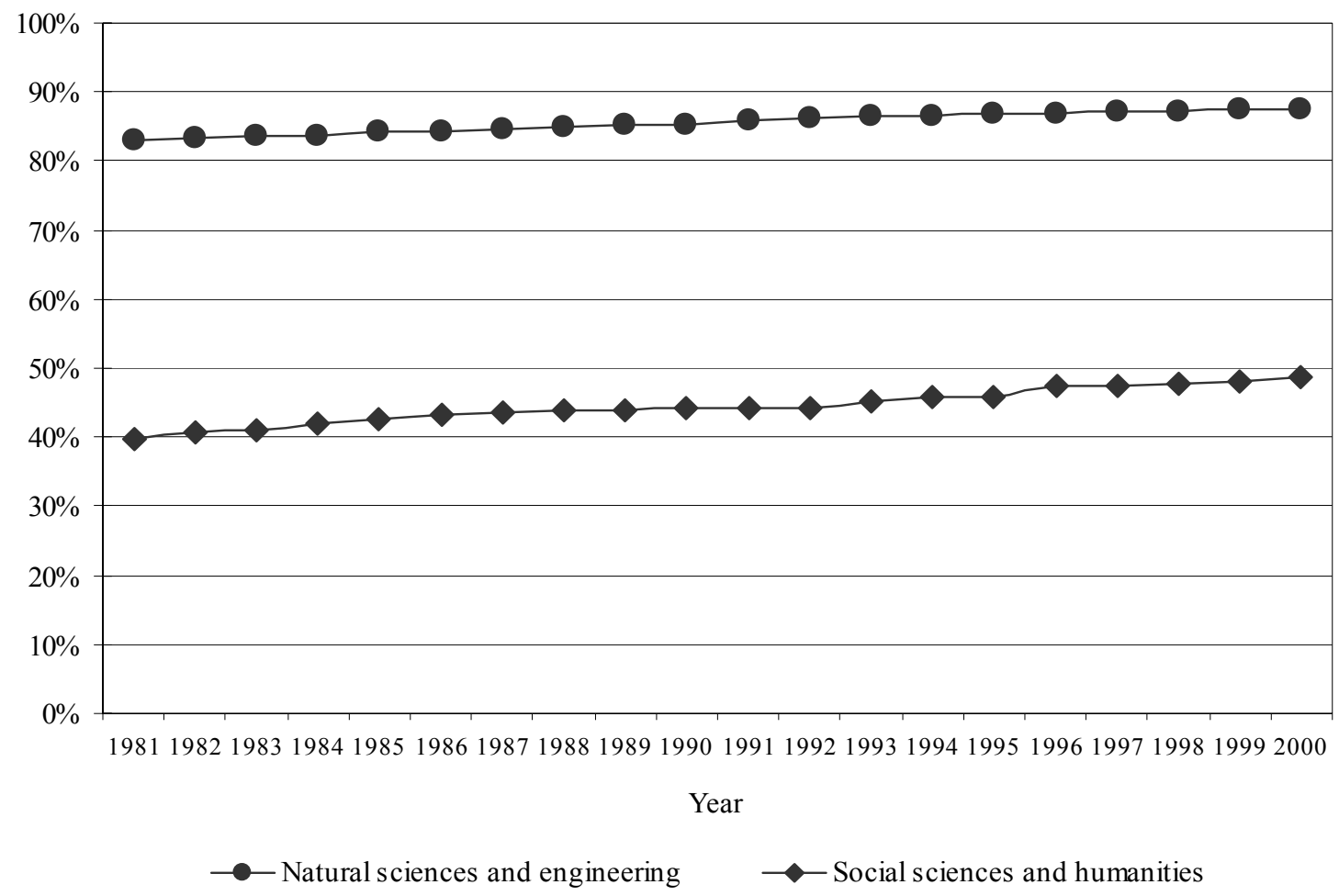

Source: SCI, SSCI and AHCI. Compiled by the Observatoire des sciences et des technologies

Figure 2 reveals four groups in the NSE that exhibit different referencing practices: the health sciences, natural sciences, mathematics and engineering. Clearly, scientists from the health sciences (biomedical research and clinical medicine) are those for whom journal papers are the most important source of scientific knowledge. In fact, this trend intensified fairly sharply during the last 20 years, increasing from more than $87 \%$ of references made to journal papers to over 93\%. This trend reflects the accelerating pace of research in these fields. The second group comprises the natural scientists (physics, biology, earth and space, and chemistry) and the psychologists. Within this group, chemists are at the top end of the spectrum (growing from $82 \%$ of cited literature in 1981 to $87 \%$ in 2000) and psychologists at the bottom (from $74 \%$ in 1981 to $79 \%$ in 2000 ). The mathematicians act as a distinct group, with around $70 \%$ of their references being made to journal papers. Finally, the engineers are citing less journal literature than others 
The Place of Serials in Referencing Practices: Comparing Natural Sciences and Engineering with Social Sciences and Humanities

but this share is rising - whereas $60 \%$ of the citations were to journal literature in 1981 , this percentage grew to almost $68 \%$ in 2000 .

As one can see here, citing practices vary greatly from one field to another and, as suggested, this must reflect the relative share of journal articles in the publication practices of these disciplines, engineers using more often than physicists, for example, conference proceedings as an outlet for their results. In addition, one can see that the calculated average does not represent a central trend within NSE, due in large part to the dispersion of referencing practices and the large proportion of health sciences papers in the SCI database.

Figure 2 Share of references made to journal articles for main fields in NSE, 1981-2000

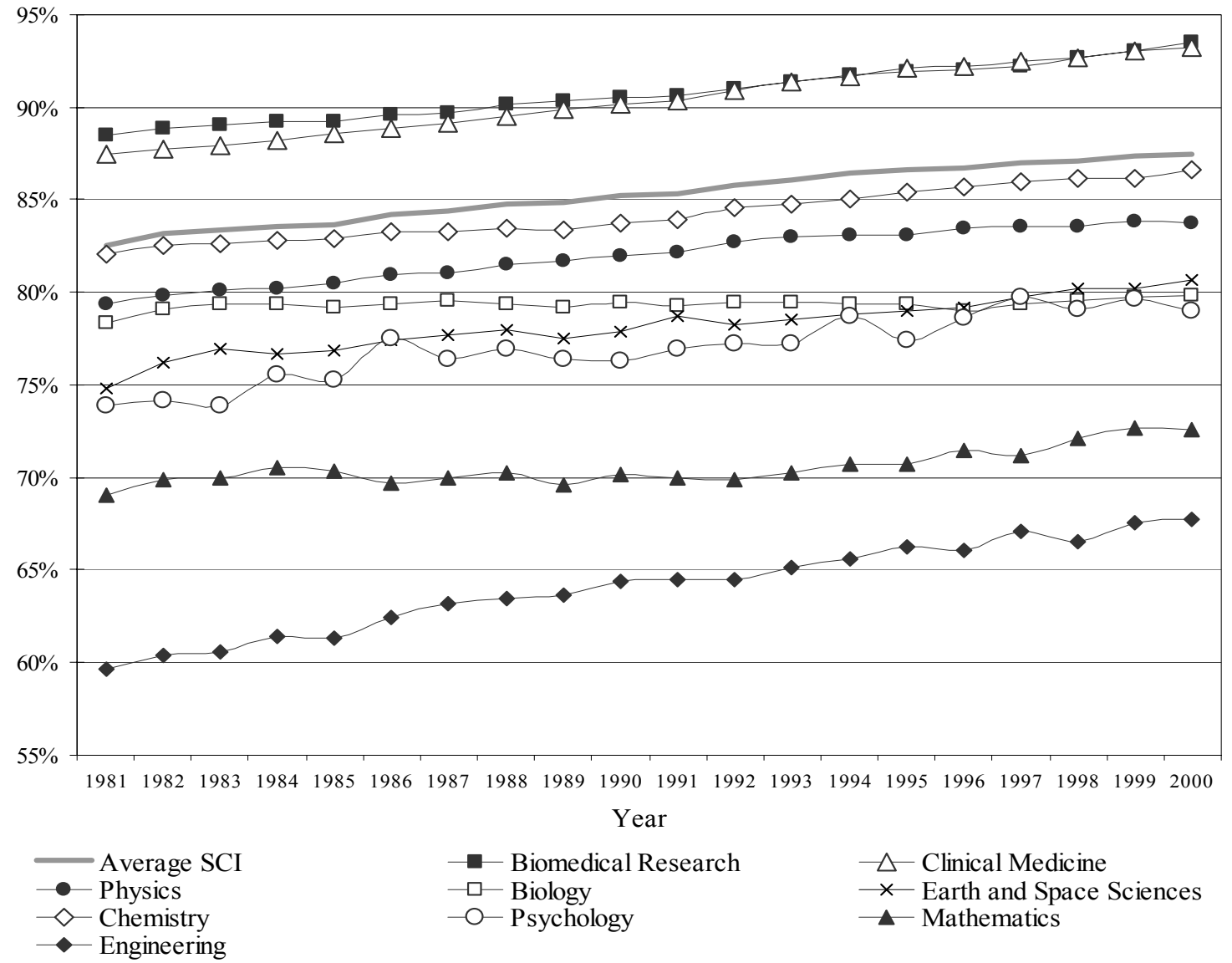

Source: SCI. Compiled by the Observatoire des sciences et des technologies 


\section{Vincent Larivière, Éric Archambault, Yves Gingras et Étienne Vignola-Gagné}

In contrast to NSE where one could see some converging patterns in different fields' citing habits, SSH presents a much larger spectrum of behaviors (Figure 3). The proportion of the psychology literature that is indexed by Thomson ISI in SSCI follows a fairly similar pattern (albeit about $10 \%$ lower) than that which is indexed in SCI. As could be expected, the proportion of references to journal articles grew rapidly in economics and management. Although the overall trend is toward an increasing percentage of references being made to journal papers, there are some fields where the proportion of references to journals decreased in the 1990s (law, history, other humanities, literature and, to a lesser extent, education).

As one can see in Figure 3, in most SSH fields, less than one reference out of two is made to a journal article. This means that bibliometricians have to apply special care in the measurement of SSH scientific outputs when using journal-based bibliometric databases.

Page 12 | CIRST - Note de recherche 2005-05 
Figure 3 Share of references made to journal articles for main fields in SSH, 1981-2000

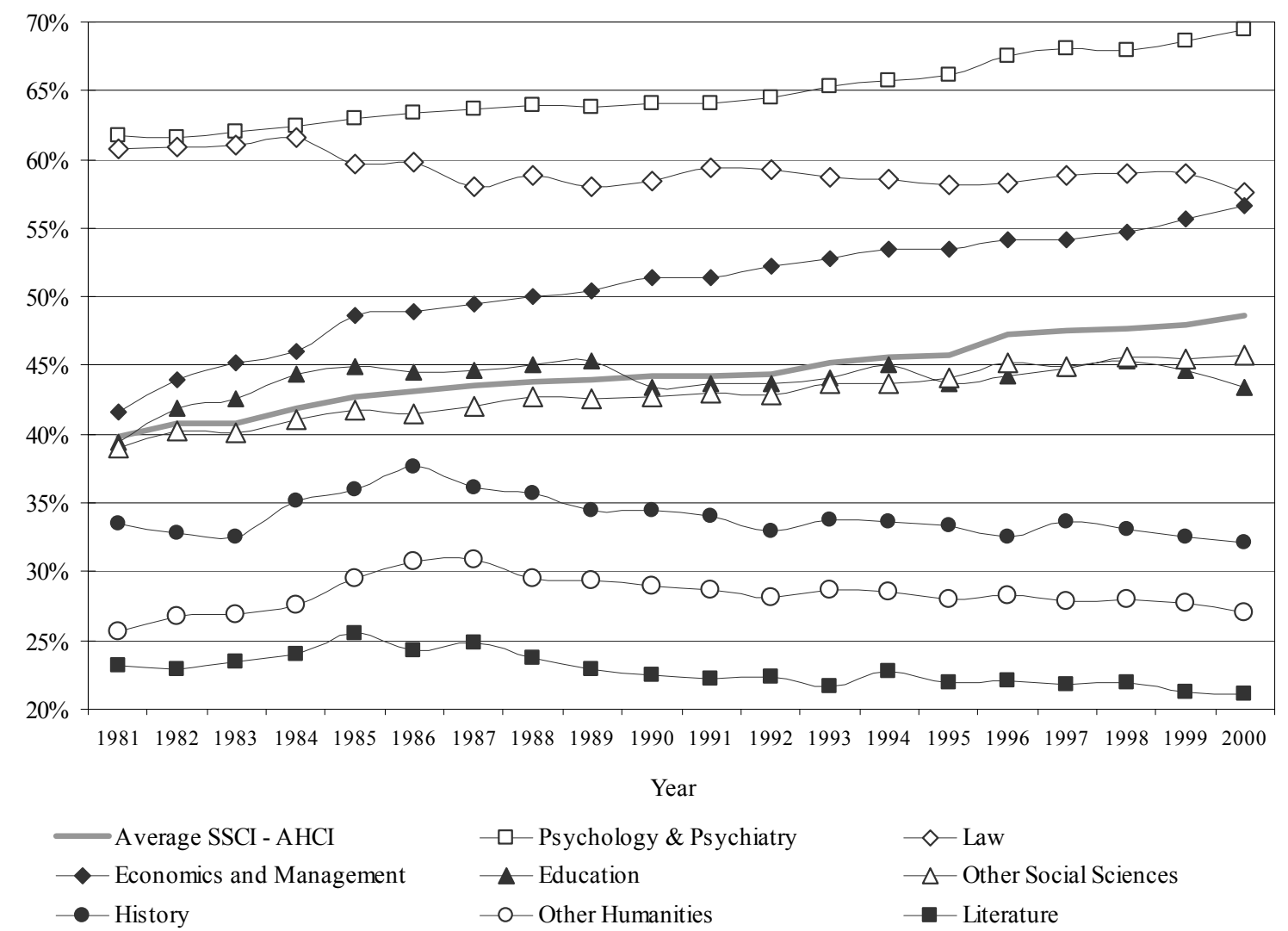

Source: SSCI and AHCI. Compiled by the Observatoire des sciences et des technologies

Given the low proportion of references made to journals in a discipline like history, one might see this as a sign that the references to non-serials are in fact references to primary sources. We can consider these sources as being references that should not be taken into account in our study since they do not play the usual role of acknowledging previous research. In fact, it can be argued that these primary sources constitute the data on which the research is often based in SSH. For instance, for an historian working on the history of astronomy, citing a book by Kepler can be considered as primary as opposed to secondary source since the discussion on the contribution of Kepler is the object of the study. By contrast, scientists in NSE rarely cite ancient literature as primary sources, given the phenomena of obliteration by incorporation (Merton, 1968). Their primary sources are, generally, experimental data. 
To ascertain that references made to primary sources were not responsible for the different proportion of references to journal articles in SSH specialties, a test was performed to characterize the age of the material being referred to. The hypothesis behind this is that if references were often made to older material in some specialties, these references would more likely be to primary rather than secondary sources. Table 1 shows that, by and large, this effect does not influence the overall results of the study. As one can see, in NSE the difference between citation patterns when it comes to newer and older material is negligible. Similarly, for most SSH fields - and even for history - this difference is also not significant. In fact, the most notable difference can be found in literature and other humanities, where the effect of citations to older material is more tangible. However, even considering the relatively small variation in the citation patterns observed, it is still undisputable that journals play a more marginal role in SSH scholarly communication than they do in NSE. 
Table 2 Share of references made to journal articles for all fields, according to the publication year of the cited article, 1981-2000

\begin{tabular}{|c|c|c|c|c|c|}
\hline Field & All References & $\begin{array}{r}\text { References made } \\
\text { to material } \\
\text { younger than } 1900\end{array}$ & $\begin{array}{r}\text { References made } \\
\text { to material } \\
\text { younger than } 1950\end{array}$ & $\begin{array}{r}\text { References made } \\
\text { to material } \\
\text { younger than } 1970\end{array}$ & $\begin{array}{r}\text { Variation } \\
\text { All/ } 1970\end{array}$ \\
\hline Mathematics & $70.8 \%$ & $73.3 \%$ & $73.1 \%$ & $73.7 \%$ & $4.1 \%$ \\
\hline Physics & $82.3 \%$ & $84.8 \%$ & $84.8 \%$ & $85.4 \%$ & $3.7 \%$ \\
\hline Psychology & $77.2 \%$ & $77.8 \%$ & $78.0 \%$ & $78.3 \%$ & $1.5 \%$ \\
\hline Chemistry & $84.6 \%$ & $85.3 \%$ & $85.2 \%$ & $85.6 \%$ & $1.2 \%$ \\
\hline Engineering & $64.8 \%$ & $66.0 \%$ & $65.9 \%$ & $65.5 \%$ & $1.2 \%$ \\
\hline Biomedical Research & $91.2 \%$ & $91.5 \%$ & $91.6 \%$ & $91.8 \%$ & $0.7 \%$ \\
\hline Clinical Medicine & $90.9 \%$ & $91.3 \%$ & $91.3 \%$ & $91.4 \%$ & $0.6 \%$ \\
\hline Earth and Space Science & $78.6 \%$ & $78.9 \%$ & $78.9 \%$ & $79.0 \%$ & $0.5 \%$ \\
\hline Biology & $79.4 \%$ & $79.7 \%$ & $79.5 \%$ & $79.1 \%$ & $-0.3 \%$ \\
\hline Science Citation Index & $85.7 \%$ & $86.4 \%$ & $86.5 \%$ & $86.8 \%$ & $1.3 \%$ \\
\hline Literature * & $23.0 \%$ & $30.4 \%$ & $30.0 \%$ & $30.4 \%$ & $32.5 \%$ \\
\hline Other Humanities * & $28.3 \%$ & $35.4 \%$ & $35.2 \%$ & $35.8 \%$ & $26.5 \%$ \\
\hline Other Social Sciences & $43.3 \%$ & $44.3 \%$ & $44.6 \%$ & $45.3 \%$ & $4.6 \%$ \\
\hline Education & $44.0 \%$ & $44.6 \%$ & $44.8 \%$ & $45.7 \%$ & $3.9 \%$ \\
\hline Economics and Management & $51.7 \%$ & $52.3 \%$ & $52.6 \%$ & $53.2 \%$ & $2.9 \%$ \\
\hline Psychology and Psychiatry & $65.5 \%$ & $66.1 \%$ & $66.4 \%$ & $67.3 \%$ & $2.8 \%$ \\
\hline Law & $59.1 \%$ & $59.6 \%$ & $59.8 \%$ & $60.3 \%$ & $2.0 \%$ \\
\hline History & $34.1 \%$ & $36.0 \%$ & $34.7 \%$ & $34.8 \%$ & $2.0 \%$ \\
\hline SSCI and AHCI & $44.7 \%$ & $48.0 \%$ & $48.5 \%$ & $49.7 \%$ & $11.0 \%$ \\
\hline
\end{tabular}

Source: SCI, SSCI and AHCI. Compiled by the Observatoire des sciences et des technologies

* Many papers in both literature and other humanities do not systematically provide a year for the cited material, which partially accounts for this variation.

One disadvantage of the method used in this paper is that it only measures references made in journals and therefore omits those made in other types of document such as books. One could argue that citations made in books follow a substantially different pattern than those made in journals. However, as suggested by some, one can expect that if books follow a different pattern of referencing they would tend to cite books more often than journal literature would (Cronin, Snyder and Atkins 1997; Line 1981). Hence, this would tend to further increase-not decrease - the measured difference in referencing patterns between specialties, thus confirming our results. 


\section{Conclusion}

Several studies have noted that journal papers were less important in the SSH than in the NSE (see e.g. Hicks, 1984) but the empirical evidence for this has, so far, been limited. For instance, Nederhof et al. (1989) have made partial measures in the case of a sample of Dutch universities departments. Small and Crane (1979) have examined the use of books in the field of sociology while Norris and Oppenheim (2003) examined the production of archeologists and Andersen (2000) inquired about the media used in the social sciences in general.

The fact that journals are not as important in the SSH as in the NSE creates a particular problem in the field of bibliometrics and scientometrics where databases that index papers published in scholarly journals are the core sources of data. Currently, we do not have systematic data on the communication habits in the various disciplines and as such it is not possible to determine, aside from using anecdotal evidence, how useful and comprehensive are current databases in the evaluation of scientific output in various scientific fields. The present paper responds to this shortcoming by providing clear evidence of the relative importance of journals in the process of knowledge diffusion for all disciplines, as measured through references and their evolution over time.

Considered as a whole, there is a trend in SSH whereby journals play an increasingly important role in knowledge building as opposed to other means of scientific diffusion. However, for certain fields such as history, the humanities and literature, this trend is less clear: over the last 10 years, the percentage of articles cited has even decreased slightly. Given that the proportion of references to journal articles is lower than $50 \%$ for many SSH fields, one should be careful in constructing performance measures on the sole basis of journal literature. Indeed, in cases where journal articles account for less than $50 \%$ of the references, the publication pattern for documents

Page 16 | CIRST - Note de recherche 2005-05 
other than journals could paint a completely different picture. For example, a department that specializes in the economics could appear to be more productive than a department focusing on medieval history, but the opposite might be true when taking into acccount book publications. In other words, evaluations based only on measures obtained from journal databases are more likely to be less than adequate for disciplines in which less than $50 \%$ of references are made to journal articles than for those in which these references account for more than 50\%. 


\section{References}

Andersen, H. (2000). Influence and Reputation in the Social Sciences-How Much Do Researchers Agree? Journal of Documentation, 56, 674-692.

Cronin, B., Snyder, H., \& Atkins, H. (1997). Comparative Citation Rankings of Authors in Monographic and Journal Literature: A Study of Sociology, Journal of Documentation, 53, 263273.

Glänzel, W. (1996). A Bibliometric Approach to Social Sciences. National Research Performance in 6 Selected Social Science Areas 1990-1992, Scientometrics, 35, 291-307.

Glänzel, W., \& Schoepflin, U. (1999). A Bibliometric Study of Reference Literature in the Sciences and Social Sciences, Information Processing and Management, 35, 31-44.

Hicks, D. (1999). The Difficulty of Achieving Full Coverage of International Social Science Literature and the Bibliometric Consequences, Scientometrics, 44, 193-215.

Hicks, D. (2004). The Four Literatures of Social Sciences, in Moed, H., Glänzel, W. \& Schmoch, U. (Eds.), The Handbook of Quantitative Science and Technology Research (pp. 473-496). Dordrecht: Kluwer Academic Publishers.

King, J. (1987). A Review of Bibliometric and Other Science Indicators and Their Role in Research Evaluation, Journal of Information Science, 13, 261-276.

Leydesdorff, L. (2003). Can Networks of Journal-Journal Citation be used as Indicators of Change in the Social Sciences? Journal of Documentation, 59, 84-104.

Line, M.B. (1981). The Structure of Social Science Literature as Shown by a Large-scale Citation Analysis, Social Science Information Studies, 1, 67-87.

Merton, R. K. (1968) Social Theory and Social Structure. New York: The Free Press.

Moed, H.F. (1996) Differences in the Construction of SCI Based Bibliometric Indicators among Various Producers: A First Overview. Scientometrics, 35, 177-191.

Nederhof, A.J., \& Noyons, E.C.M. (1992). International Comparison of Departments' Research Performance in the Humanities, Journal of the American Society for Information Science, 43, 249-256.

Nederhof A.J. and van Raan A.F.J. (1993). A bibliometric analysis of six economics research groups: A comparison with peer review. Research Policy. 22: 353-368.

Nederhof, A.J., Zwaan, R.A., Debruin, R.E., \& Dekker, P.J. (1989). Assessing the Usefulness of Bibliometric Indicators for the Humanities and the Social and Behavioral Sciences: A Comparative Study, Scientometrics, 15, 423-435.

Norris, M., \& Oppenheim, C. (2003). Citation Counts and the Research Assessment Exercise V Archaeology and the 2001 RAE, Journal of Documentation, 59, 709-730.

Page 18 | CIRST - Note de recherche 2005-05 
Schoepflin, U. (1992). Problems of Representativity in the Social Sciences Citation Index, in Weingart, P., Sehringer, R. \& Winterhager, M. (eds.). Representations of Science and Technology: Proceedings of the International Conference on Science and Technology Indicators, Bielefeld, 10-12 June 1990. Leiden: DSWO-Press. 177-188.

Small, H., \& Crane, D. (1979). Specialties and Disciplines in Science and Social Science: An Examination of Their Structure Using Citation Indexes, Scientometrics, 1, 445-461.

Treasury Board of Canada Secretariat. (2001). Evaluation Policy: Results-based Management and Accountability Framework (RMAF), Online:

http://www.tbs-sct.gc.ca/eval/tools_outils/polrmaf-polcgrr_e.asp (Checked on 15/07/2004).

Webster, B.M. (1998). Polish Sociology Citation Index as an Example of Usage of National Citation Indexes in Scientometric Analysis of Social Science, Journal of Information Science, 24, 19-32. 



\section{TITRES PARUS}

05-04 Gemme, Brigitte et Yves Gingras, «La formation à la recherche dans le cadre des collaborations université-milieu : analyse comparative des différents modes d'encadrement»

05-03 Doray, Pierre et Christian Maroy, «Le travail de rapprochements entre économie et éducation : analyse de quatre expériences de formation en alternance »

05-02 Czarnitzki, Dirk, Petr Hanel et Julio Miguel Rosa, « Evaluating the Impact of R\&D Tax Credits on Innovation : A Microeconometric Study on Canadian Firms»

05-01 Milot, Pierre, «La commercialisation des résultats de la recherche universitaire : une revue de la littérature»

04-01 Hanel, Petr, «Intellectual Property Rights Business Management Practices: A survey of literature»

03-09 Hanel, Petr, «Impact of Government Support Programs on Innovation by Canadian Manufacturing Firms»

03-08 Hanel, Petr, «Impact of innovation motivated by environmental concerns and government regulations on firm performance : a study of survey data»

03-07 Milot, Pierre, Lysanne Couture, Émilie Leblanc et Yves Gingras, «Les programmes de formation du personnel hautement qualifié dans les systèmes d'enseignement supérieur des pays de l'OCDE»

03-06 Doray, Pierre «Les parcours scolaires en sciences et technologies au collégial»

03-05 Gemme, Brigitte, Yves Gingras et Pierre Milot, «Formation à la recherche et milieu de pratique : Un portrait des étudiants et diplômés du programme «Bourses de recherche en milieu de pratique»»

03-04 Doray, Pierre, «Choix professionnel, carrières scolaires et production de la « relève » technique»

03-03 Fortier, Claire, «Les yeux grands fermés : le passage du secondaire au collégial dans des programmes de formation technique»

03-02 Milot, Pierre, «La formation postdoctorale financée par les conseils subventionnaires»

03-01 Keating, Peter et Alberto Cambrosio, «Signs, Markers, Profiles and Signatures: Clinical Haematology Meets the New Genetics (1980-2000)»

02-05 De Sousa, Maria-Philomena, «Knowledge and Rules : Hayek's social theorizing in later work»

02-04 Gentzoglanis, Anastassios, «Networks and Proximity : An Empirical Analysis»

02-03 Dodgson, Mark, «Policies for Science, Technology and Innovation in East Asia»

02-02 Pavitt, Keith, «Innovating routines in the business firm : what corporate tasks should they be accomplishing?»

02-01 Fredette, Raymond, «D'ou vient l'antiaristotélisme de Galileo Galilei?»

01-01 Castelli Gattinara, Enrico, «Épistémologie 1900: la tradition française»

00-04 Gentzoglanis, Anastassios, «Innovation and Growth in the Knowledge-based Economy»

00-03 Bouchard, Louise et Marie-Noëlle Ducharme, , «Les défis pour le travail social à l'ère des technologies de l'information»

00-02 Foisy, Martine, Yves Gingras, Judith Sévigny et Sabine Séguin, «Portrait statistique des effectifs étudiants en sciences et en génie au Québec (1970-2000)»

00-01 Prévost, Jean-Guy, « Science et fascisme le champ statistique italien (1910-1945) »

99-12 Albert, Mathieu, «Stratégies d'adaptation des organismes subventionnaires en sciences humaines et sociales au Canada et au Québec aux compressions budgétaires gouvernementales»

99-11 Godin, Benoît et Stéphane Ratel, « Jalons pour une histoire de la mesure de la science »

99-10 Gemme, Brigitte, Yves Gingras et Benoît Godin, «La commercialisation de la recherche universitaire : que disent vraiment les chiffres ?»

99-09 Albert, Mathieu et Paul Bernard, «Faire utile ou faire savant ? : La nouvelle production de connaissances et la sociologie universitaire québécoise»

99-08 Albert, Mathieu et Paul Bernard, « Sous l'empire de la science : la nouvelle production de connaissance et les sciences économiques universitaires québécoises »

99-07 Godin, Benoît et Yves Gingras, «L'impact de la recherche en collaboration et le rôle des universités dans le système de production des connaissances» 


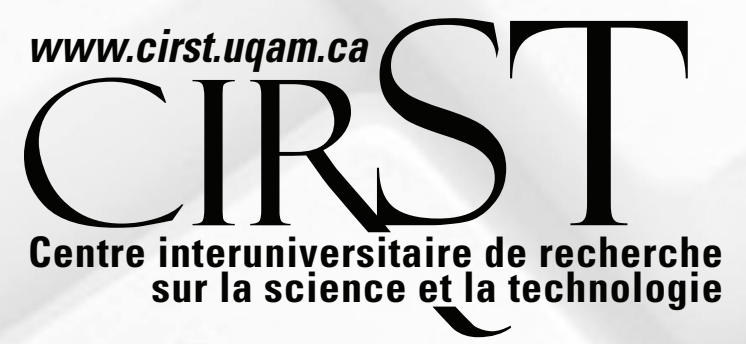

Le CIRST est, au Canada, le principal regroupement de chercheurs dont les travaux sont consacrés à l'étude des multiples dimensions de l'activité scientifique et technologique. La production régulière de travaux de recherche ainsi que la formation de nouveaux chercheurs contribuent à éclairer les débats et à informer les décideurs sur les enjeux actuels des sciences et des technologies. Ces recherches s'ordonnent autour de trois grands axes : I'analyse du développement scientifique et technologique, l'analyse socioéconomique et la gestion des technologies et enfin, l'analyse sociopolitique des usages et des incidences des technologies.

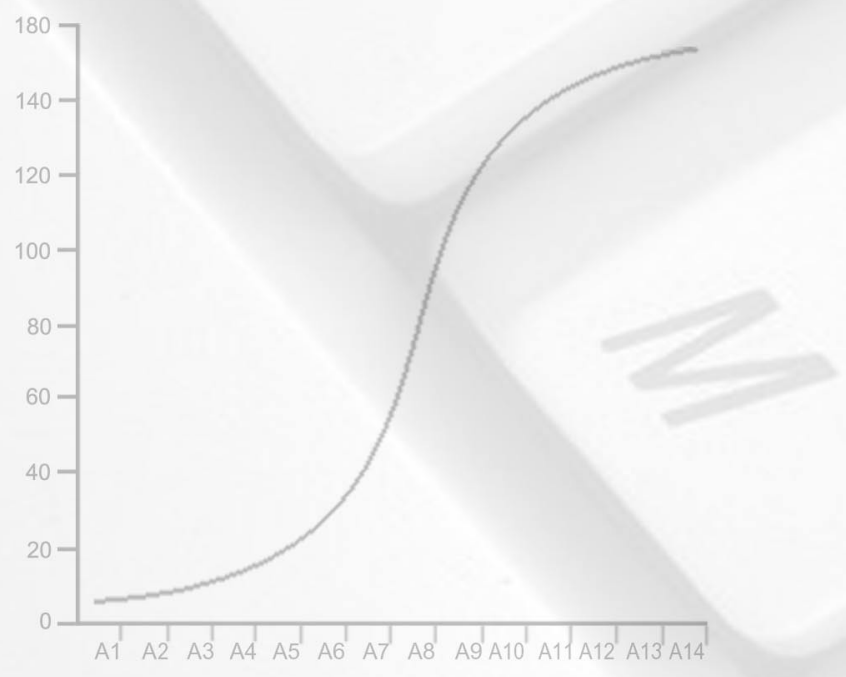

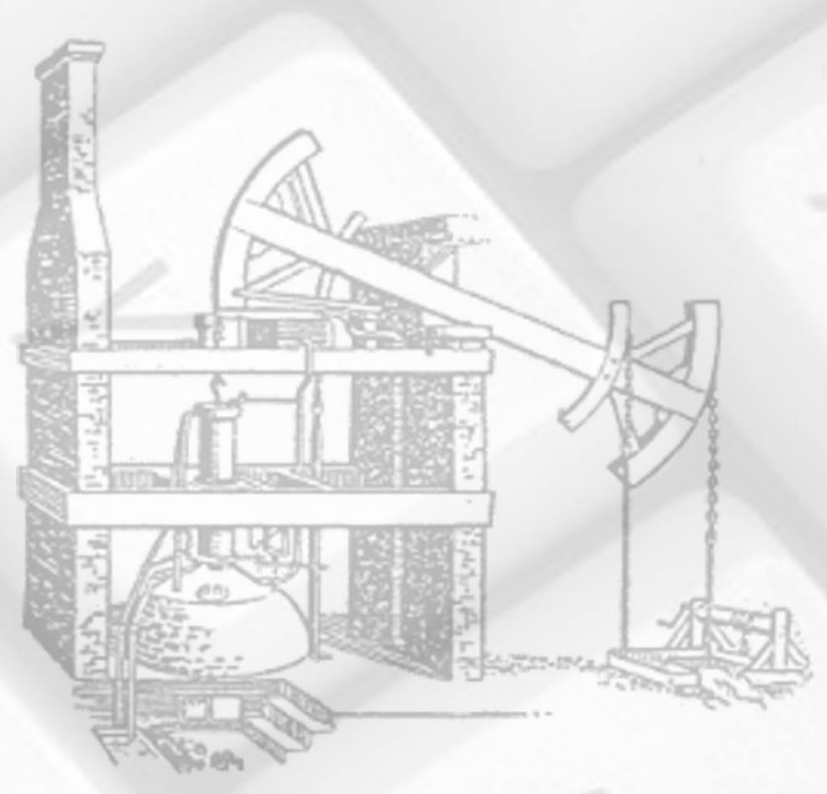

Créé en 1986, le CIRST est reconnu par quatre universités : I'Université du Québec à Montréal, I'Université de Montréal, I'Institut national de la recherche scientifique (INRS) et I'Université de Sherbrooke. II rassemble une quarantaine de chercheurs en provenance d'une douzaine d'institutions et des disciplines suivantes : histoire, sociologie, science politique, philosophie, sciences économiques, sciences administratives et communications. Le CIRST fournit un milieu de formation par la recherche à de nombreux étudiants aux cycles supérieurs dans les domaines de recherche de ses membres. 